\title{
Право на справедливий судовий розгляд в міжнародному комерційному арбітражі
}

\section{Єгор Колдов ${ }^{\mathrm{A}}$; Олег Колдов ${ }^{\mathrm{B}}$}

Received: June 3, 2020 | Revised: June 16, 2020 | Accepted: June 30, 2020

DOI: $10.33445 /$ sds.2020.10.3.6

\begin{abstract}
Анотація
Право на справедливий судовий розгляд $€$ актуальним і дискусійним, на сьогоднішній день $\epsilon$ різноманітні погляди науковців в рамках правової доктрини і правові позиції Європейського суду з прав людини. Реалізація і застосування такого права $\epsilon$ необхідною умовою для становлення демократичної держави. Виходячи із практики Європейського суду з прав людини щодо тлумачення елементів права на справедливий судовий розгляд, можна окреслити, що дане тлумачення здійснюється автономно, динамічно, Суд у певних випадках застосовує принцип пропорційності та розсуду держав. На сьогоднішній момент $\epsilon$ різне розуміння співвідношення арбітражної процедури і права на справедливий судовий розгляд, закріплене в Конвенції про захист прав людини і основоположних свобод. Адже фактично Міжнародний комерційний арбітраж лише частково регулюється національним законодавством, а більше охоплюється або угодою сторін, або власними нормами. Міжнародний комерційний арбітраж $\epsilon$ різновидом alternative dispute resolution (альтернативні способи вирішення спорів), що $є$ актуальним з точки зору дослідження, оскільки підвищення ефективності альтернативних способів $\epsilon$ можливістю розвантажити навантаження на національні суди, чим в свою чергу покращити процедуру розгляду, вирішення і виконання судових рішень. Арбітражна процедура відповідає вимогам п. 1 ст. 6 Конвенції про захист прав людини i основоположний свобод, що засвідчують відповідні правові позиції Європейського суду з прав людини. Тому, обираючи Міжнародний комерційний арбітраж сторони не обмежують себе в праві на справедливий судовий розгляд. Існують дискусійні точки зори 3 приводу деяких елементів права на справедливий судовий розгляд в рамках Міжнародного комерційного арбітражу. Як раз вимога публічності у науковців викликає різне ставлення, одні вважають, що через загальну вимогу конфіденційності це не відповідає вимогам п. 1 ст. 6 Конвенції, інші вважають, що така вимога реалізуються в рамках арбітражної процедури, хоча і не в класичному розумінні цього права.
\end{abstract}

Ключові слова: Міжнародний комерційний арбітраж, право на справедливий судовий розгляд, елементи права на справедливий судовий розгляд, арбітражна процедура, альтернативні способи вирішення спорів.

\section{Постановка проблеми}

Питання справедливого судового розгляду зараз $€$ як ніколи актуальним, враховуючи подальші реформи українського законодавця щодо імплементації норм міжнародного публічного і приватного права, приведення національного законодавства до міжнародних стандартів, адже це слугує, 3 одного боку запровадженням незалежного i неупередженого суду, а з іншого - покращує інвестиційний авторитет держави. Оскільки наявність незалежного, неупередженого судочинства $\epsilon$ гарантією обмеження

\footnotetext{
А Юрист ВМго «Федерація дебатів України», e-mail: koldov.egor@ukr.net

в Національний університет оборони України імені Івана Черняховського, начальник секретаріату Вченої Ради науково-методичного центру організації освітньої діяльності, e-mail: vchenarada301@ukr.net
} 
державного втручання у комерційні питання, питання ведення бізнесу, інвестиційного клімату і підвищеної стабільності незалежно від політичних змін.

у цьому світлі поява нових видів альтернативних способів вирішення спорів підвищує диспозитивність сторін щодо вирішення спору, розвантажує основну систему національного судочинства, чим впливає на ступінь їі ефективності та виконуваності справ, демократизує процес розгляду і вирішення спорів. Адже, коли запроваджена система альтернативного вибору, де саме має бути розглянутий спір (у суді, у міжнародному комерційному арбітражному суді, третейському суді, за допомогою процедури медіації тощо), це $\epsilon$ показником варіативної демократії. Тому не дивно, що український законодавець увів у національну правову систему сфери третейського розгляду, міжнародного комерційного арбітражу, розробляє законодавства щодо імплементації інших альтернативних способів вирішення спорів (медіація).

Останнім часом є тенденція до підвищення ролі міжнародного комерційного арбітражу і вирішення спорів у межах даного інституту серед комерційних спорів, у тому числі на основі зовнішньоекономічних договір 3 іноземним суб'єктом. Оскільки подібний розгляд має переваги для контрагентів, які не може надати суд у звичайному розумінні. На території України успішно функціонує постійно діючий Міжнародний комерційний арбітражний суд при Торгово-промисловій палаті України.

Тому в даному аспекті і виникає необхідність дослідження питань, які $\epsilon$ фундаментальними у межах розгляду спору в рамках цивільного судочинства, а саме п. 1 ст. 6 Конвенції про захист прав людини і основоположних свобод (право на справедливий судовий розгляд), у рамках арбітражної процедури розгляду як alternative dispute resolution.

\section{Аналіз останніх досліджень та публікацій}

Теоретичною основою статті стали праці українських фахівців. Зокрема, можна виокремити такі праці, як «Співвідношення міжнародного публічного і міжнародного комерційного арбітражів», Мамон 3. В.; «Арбітражна угода як умова розгляду спорів у міжнародному комерційному арбітражі», Мальський М. М.; «Принцип «компетенціїкомпетенції» в Міжнародному комерційному арбітражі», Воронов К. М.; «Міжнародний комерційний арбітраж та національні суди», Кравцов С. О.; «Міжнародно-правовий захист права на справедливий розгляд в практиці Європейського суду 3 прав людини та правозастосовна практика України», Коруц У. 3.; «Право на суд у цивільному судочинстві», Цувіна Т. А., а також окремі публікації в навчальній i науковій літературі 3 цієї проблематики.

\section{Постановка завдання}

Метою дослідження є комплексний аналіз права на справедливий судовий розгляд, закріплене у п. 1 ст. 6 Конвенції про захист прав людини i основоположних свобод, його елементів і застосування цього права (з відповідними елементами) під час розгляду комерційного спору між сторонами Міжнародним комерційним арбітражем, визначити стан такого застосування і вплив на загальну арбітражну процедуру.
Відповідно визначеної мети поставлено і вирішено такі основні завдання дослідження:

визначити елементи права на справедливий судовий розгляд, закріплене у п. 1 ст. 6 Конвенції про права людини і основоположних свобод;

проаналізувати рівень імплементації та застосування права на справедливий судовий розгляд (його елементів), закріплене у п. 1 ст. 6 Конвенції про захист прав людини i основоположних свобод, під час вирішення 


\begin{tabular}{|c|c|c|c|}
\hline $\begin{array}{l}\text { комерційного } \\
\text { комерційним ар }\end{array}$ & $\begin{array}{r}\text { спору } \\
\text { бітражем; }\end{array}$ & Міжнародним & $\begin{array}{l}\text { елементів), закріплене у п. } 1 \text { ст. } 6 \text { Конвенції про } \\
\text { захист прав людини і основоположних свобод, }\end{array}$ \\
\hline провести & компаративниі & аналіз & у рамках національних судів та Міжнародного \\
\hline $\begin{array}{l}\text { ефективності } \\
\text { справедливий }\end{array}$ & $\begin{array}{l}\text { застосування } \\
\text { судовий роз }\end{array}$ & $\begin{array}{lr}\text { права } & \text { на } \\
\text { згляд } & \text { (його }\end{array}$ & комерційного арбітражу; \\
\hline
\end{tabular}

\section{Виклад основного матеріалу}

П. 1 ст. 6 Конвенції про захист прав людини і основоположних свобод проголошує, що кожен має право на справедливий i публічний розгляд його справи упродовж розумного строку незалежним і безстороннім судом, встановленим законом, який вирішить спір щодо його прав та обов'язків цивільного характеру або встановить обґрунтованість будь-якого висунутого проти нього кримінального обвинувачення [11].

Дане право безпосередньо закріплене у Конвенції про захист прав людини і основоположних свобод, розроблена в рамках Ради Європи, тлумачиться Європейським судом з прав людини. Для України це має важливе значення, адже, поперше, Україна є членом Ради Європи, тому бере на себе міжнародні зобов'язання щодо імплементацій рішення цієї міжнародної міжурядової організації, по-друге, Україна імплементувала Конвенцію про захист прав людини і основоположних свобод, тому бере на себе зобов'язання щодо виконання положень Конвенції, по-третє, Україна визначила для себе пріоритетний напрямок щодо застосування практики Європейського суду з прав людини у практиці національних судів. Тому вивчення, дослідження, аналіз цього права $є$ складовим при встановленні демократичного, незалежного, неупередженого суду.

Аналізуючи положення п. 1 ст. 6 Конвенції можна виокремити складові елементи даної статті, зокрема: доступ до суду (судової установи); публічний розгляд справи; розгляд справи протягом розумного строку; незалежний, безсторонній суд (судова установа); суд створений на основі закону; рівності учасників.

Проте в науковій доктрині щодо елементів п. 1 ст. 6 Конвенції є різні погляди. Виділяють різні критерії для класифікації або самого права на справедливий судовий розгляд, або елементів цього права, закріпленого в Конвенції.

Одна група вчених здійснює поділ елементів на інституційні, органічні, процесуальні, спеціальні. Зокрема, М. Ентін у своїй науковій роботі класифікує елементи права на справедливий судовий розгляд на наступні: органічні (право доступу до суду (судової установи) та право на виконання рішення суду); інституційні (незалежність та неупередженість суду, встановленого законом); процесуальні (змагальність процесу, рівність сторін, розумні строки судового розгляду); спеціальні (гарантії кримінального провадження, закріплених у п. п. 2, 3 ст. 6 Конвенції про захист прав людини і основоположних свобод [8, с. 86].

Друга група вчених або об'єднує в одні групи попередню класифікацію, або виділяє додаткові критерії. Так, зокрема, М. Погорецький та І. Гриценко виділяють інституційні (створення суду на підставі закону, незалежний і неупереджений суд), організаційно-функціональні (право на доступ до правосуддя (суду), рівність сторін, право на правову допомогу, публічність судового розгляду, обов'язковість судових рішень), функціональні (змагальність процесу, розумні строки розгляду) i спеціальні (гарантії кримінального процесу, закріплені у п. п. 2,3 ст. 6 ЄКПЛ) елементи цього права [2, с. 4-5].

Характеризуючи право на справедливий судовий розгляд в Міжнародному комерційному арбітражі слід зазначити, що цей інститут не $\epsilon$ судом у формальному розумінні, це $\epsilon$ альтернативним способом вирішення спору - alternative dispute resolution (ADR), проте, виходячи із практики 
Європейського суду з прав людини, який широко тлумачить розуміння «суду», Міжнародний комерційний арбітражний суд $\epsilon$ судом у розумінні Європейського суду 3 прав людини, адже відповідає характеристикам органу, який може здійснювати вирішення справи. Тому і постає питання співвідношення арбітражу і п. 1 ст. 6 Конвенції, адже положення цієї статті $\epsilon$ основою відправлення правосуддя у класичних судах.

Практика ЄСПЛ визначає такі вимоги щодо «суду»: їх рішення $\epsilon$ обов'язкове до виконання; держава покладає на них розгляд і вирішення суспільно, юридично значущих питань; наявність законодавчої регламентації діяльності такого органу. Стосовно першої вимоги рішення арбітражного суду $\epsilon$ обов'язковим для виконання, це прямо витікає із положень ст. 35 Закону України «Про Міжнародний комерційний арбітраж», ст. 3 Конвенції про визнання і приведення до виконання іноземних арбітражних рішень 1958 р., Розділу VIII Цивільного процесуального кодексу, де прямо закріплюються положення щодо визнання i y певних випадках примусового виконання рішення арбітражу. Стосовно другої і третьої вимоги, це питання врегульовано положеннями Закону України «Про Міжнародний комерційний арбітраж».

у справі «Компанія «Регент» проти України» якраз і постало питання стосовно того, що Україна вважала, що розгляд спору і вирішення справи в арбітражному суді $\epsilon$ порушенням п. 1 ст. 6 Конвенції про захист прав і основоположних свобод, адже цей інститут не $є$ судом у класичному розумінні, тому і примусове виконання такого рішення не $€$ обов' язком держави. Європейський суд 3 прав людини зазначив попередню практику («Літгоу та інші проти Великобританії») i нагадав, що поняття «суд» тлумачиться широко, тому арбітражний суд можна вважати органом наділеним повноваженнями щодо вирішення спору, він функціонує на основі закону «Про Міжнародний комерційний арбітраж», Україна має виконувати рішення арбітражного суду [9].
Таким чином Європейський суд з прав людини у даній справі поставив крапку щодо спорів стосовно, чи $€$ арбітражний суд «судом» у класичному розумінні, тому і на арбітражну процедуру застосовуються положення п. 1 ст. 6 Конвенції. Міжнародний комерційний арбітражний суд підпадає під вимогу п. 1 ст. 6 Конвенції щодо суду, який має бути створений на основі закону.

ч. 1 ст. 55 Конституції України містить загальну норму, яка визначає право кожного звернутися до суду, якщо його права чи свободи порушені або порушуються, створено або створюються перешкоди для їх реалізації або мають місце інше обмеження прав та свобод [12].

у цьому контексті арбітражну угоду необхідно розглядати як угоду сторін, яка спрямована на встановлення за волевиявленням сторін спору обов'язкової альтернативної форми вирішення спору. При наявності такої угоди висновок про порушення прав і свобод людини може бути зроблений тільки за результатами розгляду спору у відповідному юрисдикційному органі.

У рішенні Конституційного суду України у справі за конституційним зверненням Товариства з обмеженою відповідальністю «Торговий Дім» Кампус Коттонклаб «щодо офіційного тлумачення положення частини другої статті 124 Конституції України (справа про досудове врегулювання спорів)» від 9 липня 2002 зазначено, що встановлення законом або договором досудове врегулювання спору за волевиявленням суб'єктів правовідносин не $є$ обмеженням юрисдикції судів і права на судовий захист [10].

3 відповідно до Арбітражного Регламенту ЮНСІТРАЛ, рекомендованим Генеральною Асамблеєю ООН в ії резолюції 31/98 від 15 грудня 1976 року зазначається: «якщо сторони в договорі погодилися в письмовій формі про те, що суперечки, пов'язані з цим договором, будуть передаватися на розгляд в арбітраж згідно Арбітражним регламентом ЮНСІТРАЛ, такі спори підлягають вирішенню відповідно до цього регламенту з такими змінами, про які сторони можуть домовитися 
в письмовій формі» [16]. Таким чином, досить повно закріплена юрисдикція арбітражу розглядати міжнародні комерційні суперечки на підставі арбітражної угоди.

Виходячи із практики Європейського суду з прав людини право доступу до суду досліджувалося у вже згаданих справах «Літгоу проти Вкликобританії» та «Компанія «Регент» проти України» і суд дійшов до висновку, що Конвенція не перешкоджає сторонам добровільно відмовитися від прав, наданих нею. Зокрема, ще Європейською комісією з прав людини визнавалося, що, обираючи третейський суд, заявник тим самим відмовляється від права на судовий розгляд в державному суді, що ні суперечить ст. 6 Конвенції. Внаслідок цього вибір сторонами третейського суду замість державної не може розглядатися як те, що не відповідає Конвенції (при тому, судовий контроль за дотриманням третейським судом (арбітражем) процесуальних стандартів $€$ допустимим).

У справі «Акселссон та інші проти Швеції» про визнання скарги неприйнятною ЄСПЛ наголосив, що розгляд справ у третейських судах (арбітражі) переслідує легітимну мету звільнити державні суди від надмірного навантаження [9].

У той же час право на суд в аспекті доступності суду не розглядається ЄСПЛ як абсолютне - воно може бути обмежена в інтересах належного відправлення правосуддя. Дана теза була розкрита в попередньому розділі.

Зокрема, у справі «Омар проти Франції», такі обмеження можуть бути передбачені законом щодо осіб, схильних до процесів, душевнохворих на час їх лікування, а також в інших виняткових випадках, які переслідують легітимну мету. Проте, якщо державою вводяться обмеження доступу до правосуддя, це повинно переслідувати законну мету, бути пропорційними їй з точки зору використовуваних засобів, враховувати баланс публічних і приватних інтересів і не повинно абсолютно позбавляти особу права на суд, завдавати шкоди самій суті цього права [9]. ЄСПЛ уточнює, що умови доступу до правосуддя не можуть обмежувати це право до такої міри, щоб виявилася порушеної сама його сутність.

Тому в рамках арбітражної процедури право доступу до суду не порушуються, адже само по собі право не $\epsilon$ абсолютним і може бути обмежене, вибір заявником способу захистом своїх прав і свобод $\epsilon$ проявом диспозитивності, арбітражна процедура підпадає під розуміння терміну «суд». Обираючи арбітражну процедуру і складення арбітражної угоди сторонами про розгляд комерційного спору в рамках комерційного арбітражу не $є$ порушенням чи обмеженням права доступу до суду.

Виходячи із положень ст. 23 Арбітражного регламенту ЮНСІТРАЛ, де зазначено, що встановлені арбітражним судом строки для подання письмових заяв (включаючи позовну заяву і заперечення по позовом) не повинні перевищувати 45 днів [16]. Однак арбітражний суд може продовжувати строки, якщо знаходить це виправданим.

Регламент Міжнародного комерційного арбітражного суду при Торгово-промисловій палаті України у п. 1 ст. 12 встановлює, що строки, передбачені Регламентом починають свій відлік з дня, наступного за датою, коли повідомлення або сповіщення вважається отриманим стороною (iї представником) відповідно до частини п'ятої ст. 11 Регламенту [14].

Можна дійти висновку, що положення п. 1 ст. 6 Конвенції щодо розумності строків розгляду справи застосуються і до розгляду в міжнародному комерційному арбітражі. Тим паче, враховуючи, що даний елемент права на справедливий судовий розгляд за практикою ЄКПЛ $\epsilon$ оціночною характеристикою і сам суд не визначає чітких меж, які застосовуються до розуміння розумності строків.

Міжнародний комерційний арбітраж $\epsilon$ незалежним і безстороннім органом, який може розглядати і вирішувати спори у рамках розуміння п. 1 ст. 6 Конвенції.

У міжнародному комерційному арбітражі статус арбітра визначається значним числом нормативно-правових актів: акти 
міжнародного права, національне законодавство конкретної держави (законодавчі вимоги), регламенти арбітражних інституцій (інституційні вимоги), рекомендаційні акти, прийняті професійними співтовариствами, а також безпосередніми вимогами сторін спору (погоджувальні вимоги). Яскравими прикладами міжнародних актів, що містять вимоги до арбітрів міжнародного комерційного арбітражу, можуть бути НьюЙоркська конвенція про визнання і приведення у виконання іноземних арбітражних рішень 1958 р., Європейська конвенція про зовнішньоторговельний арбітраж 1961 р., Арбітражний регламент ЮНСІТРАЛ 1976 р., Типовий закон ЮНСІТРАЛ щодо міжнародного торгового арбітражу 1985 року, Правила етики для міжнародних арбітрів 1987 р., Керівні принципи Міжнародної асоціації юристів щодо конфлікту інтересів у міжнародному арбітражі 2004 р. тощо [4, с. 69].

Регламент Міжнародного комерційного арбітражного суду при Торгово-промисловій палаті зазначає, що Міжнародний комерційний арбітражний суд є самостійною постійно діючою арбітражною установою (Третейським судом), що здійснює свою діяльність відповідно до Закону України «Про міжнародний комерційний арбітраж» [13]. Закон України «Про Міжнародний комерційний арбітраж» сторони можуть оголосити відвід арбітрам у випадку звернення до будь-якої особи у зв'язку з її можливим призначенням як арбітра ця особа повинна повідомити про будь-які обставини, які можуть викликати обґрунтовані сумніви щодо її неупередженості або незалежності.

Тому вимога незалежності і безсторонності в Міжнародному комерційному арбітражі реалізується навіть ефективніше, ніж у класичному суді. Адже вимоги для арбітрів, які можуть здійснювати розгляд справи більш жорсткіші, ніж для судів, бо включають у себе велику масу міжнароднихправових актів, крім національного регулювання; сторони самостійно узгоджують склад арбітражного суду, обирають арбітрів і можуть оголосити відвід за найменшої підозри незалежності чи безсторонності того чи іншого арбітра.

СТ. 18 Типового закону ЮНСІТРАЛ, ст. 18 Закону України «Про міжнародний комерційний арбітраж», встановлює, що до сторін повинно бути рівне ставлення, і кожній стороні повинні бути надані всі можливості для викладу своєї позиції [16].

Оскільки міжнародні-правові акти і національні закони мають відповідати вимогам Конституції України, і ці акти були ратифіковано і прийнято в систему національного законодавства, то виходячи із положень ст. 55 Конституції України громадяни мають рівні конституційні права і свободи та $€$ рівними перед законом. Не може бути привілеїв чи обмежень за ознаками раси, кольору шкіри, політичних, релігійних та інших переконань, статі, етнічного та соціального походження, майнового стану, місця проживання, за мовними або іншими ознаками. Рівність прав жінки і чоловіка забезпечується: наданням жінкам рівних з чоловіками можливостей у громадсько-політичній і культурній діяльності, у здобутті освіти і професійній підготовці, у праці та винагороді за неї; спеціальними заходами щодо охорони праці і здоров'я жінок, встановленням пенсійних пільг; створенням умов, які дають жінкам можливість поєднувати працю $з$ материнством; правовим захистом, матеріальною і моральною підтримкою материнства і дитинства, включаючи надання оплачуваних відпусток та інших пільг вагітним жінкам і матерям [12].

Виходячи із вищенаведеного вимога п. 1 ст. 6 Конвенції щодо рівності учасників, справа яких розглядається судом, реалізується і рамках Міжнародного комерційного арбітражу.

П. 1 ст. 6 Конвенції про захист прав людини i основоположних свобод передбачає елемент публічного розгляду справи у суді. 3 даним елементом виникає багато питань і на сьогоднішній день це $\epsilon$ актуальна проблема дослідження Міжнародного комерційного арбітражу, адже Закон України «Про міжнародний комерційний арбітраж» та 
Регламент Міжнародного комерційного арбітражного суду при Торгово-промисловій палаті України не містить жодних положень щодо можливості (не можливості) публікації розглянутих спорів, тому відповідно до принципу абсолютної конфіденційності Міжнародного комерційного арбітражного суду при Торгово-промисловій палаті України не публікує інформацію про розглянуті справи.

Виходячи із положень Закону України «Про Міжнародний комерційний арбітраж» за загальним правилом арбітражна процедура розгляду $\epsilon$ конференційною i сторони самостійно вирішують, що саме можна вважати публічною частиною розгляду, арбітражне рішення, як було зазначено вище не публікується, на розгляді справи не можуть бути присутніми журналісти, представники суспільства. У порівнянні з тим же Цивільно процесуальним кодексом України, який прямо закріплює у ст. 2 принцип гласності і публічності. Хоча уч. 7 ст. 7 ЦПК зазначено, що розгляд справи у закритому судовому засіданні проводиться у випадках, коли відкритий судовий розгляд може мати наслідком розголошення таємної чи іншої інформації, що охороняється законом, або за клопотанням учасників

\section{Висновки}

У результаті дослідження права на справедливий судовий розгляд у Міжнародному комерційному арбітражі автор дійшов до наступних висновків:

1. Право на справедливий судовий розгляд на сьогоднішній день по-різному визначається вченими. Правова доктрина іде таким чином, що наявні різні критерії для класифікації складових елементів права на справедливий судовий розгляд і остаточно кінцевого розуміння в даній сфері не має. Автор пропонує вважати елементами права на справедливий судовий розгляд ті, які прямо закріплені в п. 1 ст. 6 Конвенції і групувати їх за таким критеріями: інституціональні (незалежний, неупереджений суд; суд на основі закону; безсторонній суд), які визначають місце судової гілки влади в паритетності з іншими гілками справи з метою забезпечення таємниці усиновлення, запобігання розголошенню відомостей про інтимні чи інші особисті сторони життя учасників справи або відомостей, що принижують їхню честь і гідність, а також в інших випадках, установлених законом [15].

Але, сторони не зобов'язані слідувати конференційній процедурі, виходячи із принципу диспозитивності, вони можуть визначити те, що справа, яка розглядається, в рамках Міжнародного комерційного арбітражного суду є публічною.

Тому можна ствердити, що для Міжнародного комерційного арбітражу питання публічності $€$ винятком із загального правила конфіденційності, допускаючи таку можливість, а в національних судів, де правило конфіденційності $\epsilon$ винятком із загального правила гласності і відкритості. Але обидві процедури передбачають можливість існування публічного розгляду. При тому, що сам Європейський суд з прав людини допускає винятки з публічності, дозволяючи легітимно проводити закриті слухання. Можна констатувати, що вимога публічності відповідає п. 1 ст. 6 Конвенції, хоч і не в традиційному розумінні, як 3 національними судами.

влади; процесуальні (рівність учасників у процесі; розумні строки розгляду; публічний розгляд справи), які $\epsilon$ процесуальною характеристикою розгляду і вирішення справи; демократичні (доступ до суду, рівність), які визначають можливість особи звернутися за захистом свого порушеного права і бути упевненою, що їх не відмовлять.

2. Справа Європейського суду 3 прав людини «Компанія «Регент» проти України» поставило точку у дискусії стосовно розуміння сутності терміну «суд" у співвідношенні 3 Міжнародним комерційним арбітражем, за семантикою Конвенції міжнародний комерційний арбітраж є судом, у якому право на справедливий судовий розгляд реалізується і застосовується;

Елементи права на справедливий судовий 
розгляд в рамках Міжнародного комерційного арбітражу застосовуються і в деяких випадках $є$ більш жорсткими у порівнянні з регулюванням у національних судах цивільного судочинства, на приклад, вимога незалежності, безсторонності суду. В рамках Міжнародного комерційного арбітражу дана вимога застосовується ефективніше, адже сторони мають право самостійно обирати склад арбітражного суду, оголошувати відводи при найменшій підозрі зменшення незалежності чи безсторонності.

\section{Список використаних джерел}

1. Воронов К. М. Принцип «компетенціїкомпетенції» в Міжнародному комерційному арбітражі: дис. ... канд. юрид. наук : 12.00.03. Харків. 2018. с. 207

2. Гриценко І., Погорецький М. Право на справедливий суд. Вісник Київського національного університету імені Тараса Шевченка. Серія «Юридичні науки». 2012. № 91. c. 4-5.

3. Коруц У. Міжнародно-правовий захист права на справедливий судовий розгляд в практиці Європейського суду з прав людини та правозастосовна практика України: дис. ... канд. юрид. наук : 12.00.11. Київ. 2015. с. 229

4. Кравцов С. Міжнародний комерційний арбітраж та нацональні суди. Дисертація на здобуття наукового ступеня кандидата юридичних наук за спеціальністю 12.00.03. Харків, 2012. с. 208

5. Мамон 3. Співвідношення міжнародного публічного і міжнародного комерційного арбітражів: дис. ... канд. юрид. наук : 12.00.03. Київ. 2011. с. 185

6. Мальський М. Арбітражна угода: теоретичні та практичні аспекти: Монографія. Літопис. Львів. 2013. с. 374

7. Цувіна Т. Право на суд у цивільному судочинстві : дис. ... канд. юрид. наук : 12.00.03. Харків. 2013. с. 265

8. Энтин М. Справедливое судебное разбирательство по праву Совета Европы и Европейского Союза. Конституционное право: восточноевропейское обозрение. 2003. № 3. с. 85-97.

9. Посібник ст. 6. Право на справедливий суд. URL: https://www.echr.coe.int/Documents/ Guide_Art_6_UKR.pdf

10. Рішення Конституційного суду України від 9 липня 2002 р. у справі за конституційним зверненням Товариства 3 обмеженою відповідальністю «Торговий Дім» Кампус
Коттонклаб «щодо офіційного тлумачення положення частини другої статті 124 Конституції України (справа про досудове врегулювання спорів)». URL: https://zakon.rada.gov.ua/laws/show/v015p7 10-02

11. Конвенції про захист прав людини i основоположних свобод. URL: https://zakon.rada.gov.ua/laws/show/995_00 4

12. Конституція України. Відомості Верховної Ради України. 1996. № 30. ст. 141. URL: https://zakon.rada.gov.ua/laws/show/254\%D 0\%BA/96-\%D0\%B2\%D1\%80

13. Закон України «Про Міжнародний комерційний арбітраж». Відомості Верховної Ради України. 1994. № 25. ст.198. URL: https://zakon.rada.gov.ua/laws/show/ 4002-12

14. Регламент Міжнародного комерційного арбітражного суду при Торговопромисловій палаті України. URL: https://icac.org.ua/wp-content/uploads/ Reglament-ISAS-pry-TPP-Ukrayny.pdf

15. Цивільний процесуальний кодекс України. Відомості Верховної Ради України. 2004. № 40-41, 42. ст.492. URL: https://zakon.rada.gov. ua/laws/show/1618-15

16. Арбітражний регламент ЮНСITPAЛ. URL: https://zakon.rada.gov.ua/laws/show/995_05 9

17. Типовий закон ЮНСІТРАЛ щодо міжнародного торгівельного арбітражу принятий на 18 сесії ЮНСITPAЛ. URL: https://zakon.rada.gov.ua/laws/show/995_87 9

18. Конвенція про визнання та виконання іноземних арбітражних рішень. URL: https://zakon.rada.gov.ua/laws/show/995_07 0 


\title{
Право на справедливое судебное разбирательство в международном коммерческом арбитраже
}

\author{
Егор Колдов ${ }^{\text {; }}$ Олег Колдов ${ }^{\text {B }}$ \\ А Юрист ВМго «Федерация дебатов Украины», e-mail: koldov.egor@ukr.net \\ В Национальный университет обороны Украины имени Ивана Черняховского, начальник секретариата \\ ученого совета научно-методического центра организации образовательной деятельности, \\ e-mail: vchenarada301@ukr.net
}

\begin{abstract}
Аннотация
Право на справедливое судебное разбирательство является актуальным $и$ дискуссионным, на сегодняшний день есть различные взгляды ученых в рамках правовой доктрины и правовых позициях Европейского суда по правам человека. Реализация и применение такого права является необходимым условием для становления демократического государства. Исходя из практики Европейского суда по правам человека относительно толкования элементов права на справедливое судебное разбирательство, можно определить, что данное толкование осуществляется автономно, динамично. Суд в определенных случаях применяет принцип пропорциональности и усмотрения государств. На сегодняшний момент есть разное понимание соотношения арбитражной процедуры и права на справедливое судебное разбирательство, закрепленное в Конвенции о защите прав человека и основных свобод. Ведь фактически Международный коммерческий арбитраж частично регулируется национальным законодательством, а больше охватывается или соглашением сторон, или собственными нормами. Международный коммерческий арбитраж является разновидностью alternative dispute resolution (альтернативные способы разрешения споров), что является актуальным с точки зрения исследования, поскольку повышения эффективности альтернативных способов является возможностью разгрузить нагрузку на национальные суды, чем в свою очередь улучшить процедуру рассмотрения, решения и исполнения судебных решений. Арбитражная процедура соответствует требованиям п. 1 ст. 6 Конвенции о защите прав человека и основных свобод, удостоверяющих соответствующие правовые позиции Европейского суда по правам человека. Поэтому, выбирая Международный коммерческий арбитраж, стороны не ограничивают себя в праве на справедливое судебное разбирательство. Существуют дискуссионные точки зрения по поводу некоторых элементов права на справедливое судебное разбирательство в рамках Международного коммерческого арбитража. Как раз требование публичности в научных кругах вызывает разное отношение, одни считают, что через общее требование конфиденциальности это не соответствует требованиям п. 1 ст. 6 Конвенции, другие считают, что такое требование реализуются в рамках арбитражной процедуры, хотя и не в классическом понимании этого права.
\end{abstract}

Ключевые слова: Международный коммерческий арбитраж, право на справедливое судебное разбирательство, элементы права на справедливое судебное разбирательство, арбитражная процедура, альтернативные способы разрешения споров.

\section{The right to a fair trial in international commercial arbitration}

\author{
Yehor Koldov ${ }^{\text {; }}$ Oleh Koldov ${ }^{\text {B }}$ \\ A Lawyer of the NGO Federation of Debates of Ukraine, e-mail: koldov.egor@ukr.net \\ B The National Defence University of Ukraine named after Ivan Cherniakhovskyi, Head of the Secretariat of the Academic \\ Council of the Scientific and Methodological Center for the Organization of Educational Activities, \\ e-mail:vchenarada301@ukr.net
}




\begin{abstract}
The right to a fair trial is relevant and debatable, there are different views of scholars within the legal doctrine and the legal position of the European Court of Human Rights today. The realization and application of such a right is a necessary condition for the establishment of a democratic state. Based on the case law of the European Court of Human Rights on the interpretation of the elements of the right to a fair trial, it can be stated that this interpretation is carried out autonomously and dynamically. The Court in some cases applies the principle of proportionality and discretion. Now there is a different understanding of the relationship between arbitration and the right to a fair trial enshrined in the Convention for the Protection of Human Rights and Fundamental Freedoms. In fact, International Commercial Arbitration is only partially regulated by national law and is more covered either by agreement between the parties or by its own rules. International commercial arbitration is a type of alternative dispute resolution that is relevant from the research point of view, as increasing the effectiveness of alternative methods is an opportunity to relieve the burden on national courts, which in turn improves the procedure of reviewing, resolving and enforcing judgments. The arbitration procedure meets the requirements of paragraph 1 of Art. 6 of the Convention for the Protection of Human Rights and Fundamental Freedoms, which certify the relevant legal positions of the European Court of Human Rights. Therefore, the parties do not limit themselves in the right to a fair trial when choosing International Commercial Arbitration. There are controversial views on some elements of the right to a fair trial in International Commercial Arbitration. It is the requirement of publicity that causes a different attitude among scholars. Some believe that due to the general requirement of confidentiality, it does not meet the requirements of paragraph 1 of Art. 6 of the Convention, others believe that such a requirement is implemented through arbitration, although not in the classical sense of the law.
\end{abstract}

Keywords: International commercial arbitration, right to a fair trial, elements of the right to a fair trial, arbitration procedure, alternative dispute resolution.

\title{
References
}

1. Voronov K. M. (2018) Pryntsyp «kompetentsiikompetentsii $\quad \mathrm{v} \quad$ Mizhnarodnomu komertsiinomu arbitrazhi [The principle of "competence-competence» in International Commercial Arbitration]: dys. ... kand. yuryd. nauk : 12.00.03. Kharkiv. p. 207

2. Hrytsenko I., Pohoretskyi M. (2012) Pravo na spravedlyvyi sud [The right to a fair trial]. Visnyk Kyivskoho natsional-noho universytetu imeni Tarasa Shevchenka. Seriia «lurydychni nauky». no. 91. pp. 4-5.

3. Koruts U. (2015) Mizhnarodno-pravovyi zakhyst prava na spravedlyvyi sudovyi rozghliad $v$ praktytsi Yevropeiskoho sudu z prav liudyny ta pravozastosovna praktyka Ukrainy [International legal protection of the right to a fair trial in the case law of the European Court of Human Rights and law enforcement practice of Ukraine]: dys. ... kand. yuryd. nauk : 12.00.11. Kyiv. p. 229
4. Kravtsov S. (2012) Mizhnarodnyi komertsiinyi arbitrazh ta natsonalni sudy [International Commercial Arbitration and National Courts]. Dysertatsiia na zdobuttia naukovoho stupenia kandydata yurydychnykh nauk za spetsialnistiu 12.00.03. Kharkiv. p. 208

5. Mamon Z. (2011) Spivvidnoshennia mizhnarodnoho publichnoho i mizhnarodnoho komertsiy̆noho arbitrazhiv [The ratio of international public and international commercial arbitration]: dys. ... kand. yuryd. nauk : 12.00.03. Kyiv. p. 185

6. Malskyi M. (2013) Arbitrazhna uhoda: teoretychni ta praktychni aspekty [Arbitration agreement: theoretical and practical aspects]: Monohrafiia. Litopys. Lviv. p. 374

7. Tsuvina T. (2013) Pravo na sud u tsyvilnomu sudochynstvi [The right to a court in civil proceedings]: dys. ... kand. yuryd. nauk : 12.00.03. Kharkiv. p. 265 
8. Эntyn M. (2003) Spravedlyvoe sudebnoe razbyratelstvo po pravu Soveta Evropы y Evropeiskoho Soiuza [A fair trial under the law of the Council of Europe and the European Union]. Konstytutsyonnoe pravo: vostochnoevropeiskoe obozrenye. no. 3. pp. 85-97.

9. Posibnyk st. 6. Pravo na spravedlyvyi sud [Manual of Art. 6. The right to a fair trial]. URL: https://www.echr.coe.int/Documents/Guide_ Art_6_UKR.pdf

10. Rishennia Konstytutsiinoho sudu Ukrainy vid 9 lypnia 2002 r. u spravi za konstytutsiinym zvernenniam Tovarystva $\mathrm{z}$ obmezhenoiu vidpovidalnistiu «Torhovyi Dim» Kampus Kotton-klab «shchodo ofitsiinoho tlumachennia polozhennia chastyny druhoi statti 124 Konstytutsii Uk-rainy (sprava pro dosudove vrehuliuvannia sporiv)» [Judgment of the Constitutional Court of Ukraine of 9 July 2002 in the case of the constitutional appeal of the Trading House Limited Liability Company "Cotton Campus Campus» regarding the official interpretation of the second part of Article 124 of the Constitution of Ukraine (case on pre-trial settlement of disputes)]. URL: https://zakon.rada.gov.ua/laws/show/v015p7 10-02

11. Konventsii pro zakhyst prav liudyny i osnovopolozhnykh svobod [Convention for the Protection of Human Rights and Fundamental Freedoms]. URL: https://zakon.rada.gov.ua/ laws/show/995_004

12. Konstytutsiia Ukrainy [The Constitution of Ukraine] (1996). Vidomosti Verkhovnoi Rady Ukrainy. no. 30. Art. 141. URL:
https://zakon.rada.gov.ua/laws/show/254\%D 0\%BA/96-\%D0\%B2\%D1\%80

13. Zakon Ukrainy «Pro Mizhnarodnyi komertsiinyi arbitrazh» [Law of Ukraine «On International Commercial Arbitration»] (1994). Vidomosti Verkhovnoi Rady Ukrainy. no. 25. Art. 198. URL: https://zakon.rada.gov.ua/ laws/show/4002-12

14. Rehlament Mizhnarodnoho komertsiinoho arbitrazhnoho sudu pry Torhovo-promyslovii pa-lati Ukrainy [Rules of Procedure of the International Commercial Arbitration Court at the Chamber of Commerce and Industry of Ukraine]. URL: https://icac.org.ua/wpcontent/uploads/Reglament-ISAS-pry-TPPUkrayny.pdf

15. Tsyvilnyi protsesualnyi kodeks Ukrainy [Civil Procedure Code of Ukraine] (2004). Vidomosti Verkhovnoi Rady Ukrainy. no. 40-41, 42. Art. 492. URL: https://zakon.rada.gov.ua/ laws/show/1618-15

16. Arbitrazhnyi rehlament YUNSITRAL [UNCITRAL Arbitration Rules]. URL: https://zakon.rada. gov.ua/laws/show/995_059

17. Typovyi zakon YuNSITRAL shchodo mizhnarodnoho torhivelnoho arbitrazhu pryniatyi na 18 sesii YUNSITRAL [UNCITRAL Model Law on International Commercial Arbitration adopted at the 18th session of UNCITRAL]. URL: https://zakon.rada.gov.ua/ laws/show/995_879

18. Konventsiia pro vyznannia ta vykonannia inozemnykh arbitrazhnykh rishen [Convention on the Recognition and Enforcement of Foreign Arbitral Awards]. URL: https://zakon.rada.gov. ua/laws/show/995_070. 